\title{
Acute Myocardial Infarction Incidence, Mortality and Case Fatality in Santa Clara, Cuba, 2007-2008
}

\author{
Alberto Morales MD MPH, Yuri Madrazo MD, José I. Ramírez MD, Luis Castañeda MD PhD, Wilfredo Machín MD PhD, \\ Licet Álvarez MD, Regla Angulo MD MPH, Raúl Dueñas MD MPH, Roberto Bermúdez MD
}

\begin{abstract}
INTRODUCTION Information on acute myocardial infarction incidence and mortality is essential for determining the efficacy of the health system's cardiovascular disease prevention activities; however, in Cuba, sufficient data related to acute myocardial infarction are lacking, particularly at the local level.

OBJECTIVE Describe acute myocardial infarction incidence, mortality and case fatality rates from January 2007 through December 2008 in persons aged 45-74 in the municipality of Santa Clara, Villa Clara Province, Cuba.

METHODS A retrospective descriptive study was conducted. The World Health Organization MONItoring Trends and Determinants in CArdiovascular Disease Project (MONICA) methodology was used, but only in part, since out-of-hospital case fatalities were not investigated, resulting in insufficient data for such cases. Cases of acute myocardial infarction covered under MONICA definition 1 were included (non-fatal definite, fatal definite, fatal possible, and unclassifiable deaths). Hospitalized patients were followed for 28 days. Incidence, mortality and case fatality rates in the population were calculated by age group (45-54, 55-64 and 65-74 years) and sex. Age-standardized incidence and mortality rates were calculated using the direct method, with the world population as a reference.
\end{abstract}

RESULTS A total of 482 cases of acute myocardial infarction were registered. The percentage of cases of non-fatal definite, fatal definite, fatal possible and fatal with insufficient data were $32 \%, 18.3 \%, 26.3 \%$ and $13.9 \%$ respectively. The cumulative agestandardized incidence per 100,000 population was $433(95 \% \mathrm{Cl}$ $365-501)$ in men and 195 (95\% Cl 152-237) in women, while mortality per 100,000 population was $242(95 \%$ Cl 192-292) in men and $120(95 \% \mathrm{Cl} 87-153)$ in women. Case fatality was $56.4 \%$ in men and $62.6 \%$ in women. Most fatal cases $(65.6 \%)$ occurred out of hospital, a trend that was more marked in men $(73.9 \%)$ than in women $(51 \%)$.

CONCLUSIONS Case fatality from acute myocardial infarction in Santa Clara residents was high, especially in women. Two thirds of fatalities occurred out of hospital, a higher proportion of these deaths in men. It is recommended that the AMI registry be completed by investigating out-of-hospital case fatalities with insufficient data; expanding it to include the 35-44 age group; and that the supply of cardiac marker enzyme immunoassay test kits in Santa Clara be stabilized.

KEYWORDS Myocardial infarction, heart disease, cardiovascular disease, chronic disease, epidemiology, mortality, incidence, surveillance, registries, Cuba

\section{INTRODUCTION}

Chronic non-communicable diseases (NCD) - mainly cardiovascular diseases (CVD), cancer, diabetes mellitus and chronic obstructive pulmonary disease-are responsible for roughly $60 \%$ of all deaths worldwide. Some $78 \%$ of deaths from NCDs and $85 \%$ of deaths from CVDs are in low- and middle-income countries.[1]

Elevated CVD burden in developing countries appears to be attributable to increasing incidence of atherosclerotic diseases; population growth; urbanization; drug shortages in public health services; and high prevalence of risk factors such as obesity, diabetes, dyslipidemia and hypertension.[1,2] Deaths from ischemic heart disease (IHD) - the principal cause of CVD deaths-are projected to increase in developing countries by $120 \%$ in men and $137 \%$ in women between 1990 and 2020, increases far greater than those anticipated in developed countries $(29 \%$ and $48 \%$, respectively).[1]

In Cuba, IHD mortality rates fell substantially between 1990 and 2005. Nevertheless, since 2000 , these rates have stabilized or reintroduced an upward trend.[3] Taken together, CVDs remain the leading cause of death and potential years of life lost in the country, accounting for $33 \%$ of the latter.[3,4] Thus, CVDs continue to be Cuba's main health problem.

One of the main international recommendations for CVD prevention in each country is to implement systematic surveillance of IHD and record risk factor trends to use in national policy-making.
$[5,6]$ Cuba has a relatively long history of population health statistical record-keeping and registries.[7]

It is well established that adequate surveillance of IHD and other NCDs requires three elements: risk factors; incidence; and mortality.[8] In Cuba, the National Risk Factor Surveys, [9] as well as the 10 de Octubre,[10] Global Cienfuegos[11,12] and PAHO's Collaborative Action for Risk Factor Prevention and Effective Management of Non-Communicable Diseases (CARMEN) initiative[12,13] have helped identify risk factor trends over the past 20 years. Mortality from CVD has been monitored since 1970, when mortality registries were established.[14]

However, comprehensive incidence data are scarce:[14] there is no national registry for acute myocardial infarction (AMI),[15] and, for example, the Anuario Estadístico de Salud 2009 [Health Statistics Yearbook 2009] contains only three tables on cardiovascular morbidity related to hospital discharge diagnosis, with estimates based on a sample of 35 hospitals.[4]

A number of methods have been employed to estimate IHD incidence, including use of information on hospitalized cases[14] and from death certificates.[16] Annual AMI risk and case fatality rates have even been estimated by hospital admission diagnosis of ST-Elevated AMI (STEMI).[17,18] However, WHO recommends monitoring infarction incidence through population registries, which should investigate all death certificates and autopsies with relevant diagnoses, as well as hospital admissions/discharges 
and information from medical transport systems of all hospitals in their catchment area.[19,20]

Population-based AMI registries enable calculation of IHD incidence, mortality and case fatality rates and point out trends if registration is continuous. Such registries are uncommon and are carried out mainly in developed countries, since they are expensive and difficult to conduct, requiring a complex organizational network involving multidisciplinary collaboration among cardiologists, intensive and urgent care specialists and epidemiologists.[19,20]

The best-known population registry is WHO's MONICA Project, which analyzes AMI trends in persons aged 35-64 years in 37 populations in 21 countries-primarily in Europe, although it also includes the United States, Canada, New Zealand, Australia and China.[21]

Using MONICA methodology, therefore, facilitates comparison of results across regions, as done by one of the most prestigious studies in Spain, REgistre Glroní del COR (REGICOR), which analyzes AMI trends in a broader age group (35-74 years).[22]

MONICA was launched in 1984 to monitor IHD mortality and morbidity trends, acute coronary care and risk factors, and to determine whether changes in IHD mortality trends were related to changes in incidence or case fatality rates.[20,21] REGICOR was initiated in 1978 as a hospital-based registry and extended in 1990 to cover part of the municipality of Girona, Catalonia. [20] Its multidisciplinary research team has made significant contributions to cardiovascular epidemiology[22-26] and has collaborated with investigators at the Villa Clara Heart Center in Cuba.[27-30]

With guidance from REGICOR and motivated by the need to lay the foundations for a population-based AMI registry, this study was designed to describe AMI incidence, mortality, and case fatality rates in 2007 and 2008 in the population aged 45-74 in the municipality of Santa Clara, Villa Clara Province, Cuba.

\section{METHODS}

A retrospective descriptive study of AMI morbidity and mortality was conducted, incorporating aspects of retrospective cohort analysis for case fatality. It included all AMI cases in 2007 and 2008 in the population aged $45-74$ in the Santa Clara municipality, capital of Villa Clara Province, Cuba.

In order to get closer to the upper age limit for life expectancy at birth for the Cuban population, which is currently 78,[4] we excluded the youngest age group used in the MONICA project (35-44 years) and added an older group not analyzed by MONICA (65-74 years).

Study area demographics Santa Clara municipality is located in central Cuba, its population of 159,362 constituting $19.7 \%$ of that of Villa Clara Province, according to 2007 data; with $45.3 \%$ (34,341 men and 37,818 women) aged 45-74 (unpublished data, Villa Clara Province Health Statistics Bureau).

Data collection The MONICA algorithm was used for case classification, although only partially, since out-of-hospital fatal cases with insufficient data were not included. Detailed methodology for detecting and classifying cases is published on the MONICA website.[31] In brief, the classification depends on symptoms; electrocardiographic findings; enzymes; and, for fatal cases detected solely by death certificate, a history of IHD and autopsy results, if performed. Cases classified under MONICA definition 1-definite AMI, fatal or non-fatal; fatal possible AMI, and unclassifiable deaths-were included in the study. Researchers retrieved clinical information for the first 28 days following admission with AMI diagnosis.[31]

MONICA forms were used for data collection.[31] Sources of information were patient discharge lists, clinical records, death certificates and autopsy records from the three city hospitals with cardiac intensive care units (the Arnaldo Milián Castro, Celestino Hernández Robau and Comandante Manuel Piti Fajardo hospitals). Patients who died out of hospital were identified through death certificate review and the Santa Clara death registry.

\section{Study variables}

Diagnostic categories under the MONICA algorithm[31]

(1) Definite AMI:

a. Living patient meeting 2 or more the following criteria: typical angina, typical AMI changes in ECG and positive enzymes.

b. Fatal case, whether or not from sudden death, in which signs suggestive of AMI or recent coronary occlusion are observed on autopsy or indicated in clinical records.

(2) Possible AMI:

a. Living patient with typical symptoms, whose ECG and enzymes do not permit classification in category 1 and with no evidence of another diagnosis.

b. Fatal case, whether or not from sudden death, with no clear evidence of another cause of death, clinically or on autopsy,

- with typical, atypical or inadequately-described symptoms; or,

- without typical, atypical or inadequately described symptoms, but with evidence of chronic coronary occlusion, stenosis or old AMI on autopsy; or,

- with history of chronic IHD, such as definite or possible AMI, angina or coronary insufficiency.

(3) Neither AMI nor death of coronary origin:

a. Living patient

- with a combination of symptoms and diagnostic tests do not support classification as "definite", nor typical symptoms that would permit classification as "possible"; or in whom the episode can be explained by another diagnosis.

b. Fatal case:

- in which another clinical diagnosis or diagnosis on autopsy is determined as the cause of death.

(4) Unclassifiable deaths: fatal cases without autopsy or data on symptoms or history of ischemia.

Annual rates:[22]

1. Cumulative incidence: number of AMI cases (first or recurrent) per 100,000 inhabitants.

2. Mortality: fatal cases per 100,000 inhabitants.

3. Case fatality in the population: proportion of fatal cases in the first 28 days among all patients with AMI in the region studied. 
Place of death:

1. In hospital: deaths occurring in hospitals (including emergency services) or polyclinic intensive care units.

2. Out of hospital: deaths that do not occur in hospitals or polyclinic intensive care units.

Analysis The population of Santa Clara in 2007 was used to calculate annual incidence and mortality rates. Rates were directly standardized to the 2007 world population[22,32] and, in addition, were compared with those of each of the MONICA countries. SPSS for Windows 10 was used for analysis.

Comparison between Cuban and other country rates: comparison country ratios of 0.95-1.05 were defined as similar. In MONICA countries with more than one population represented, the rate was selected for the region with the highest number of IHD deaths.

Ethical aspects The ethics committee of the Medical University of Villa Clara approved the study design, which involved the use of patient records and other administrative data, with appropriate data management procedures to ensure patient confidentially.

\section{RESULTS}

In 2007-2008, 482 cases (66.2\% of them men) were reported, $288(59.8 \%)$ classified as definite AMI (fatal or not) and the rest as fatal possible AMI or unclassifiable deaths (Table 1).

Cumulative age-standardized AMI incidence was 433 per 100,000 population (95\% Cl 365-501) in men and 195 (95\% Cl 152-237) in women, while standardized mortality rates per 100,000 population were $242(95 \% \mathrm{Cl} 192-292)$ in men and $120(95 \% \mathrm{Cl}$ 87-153) in women (Table 2).

AMI case fatality in the population was $58.5 \%(282 / 482)$, higher in women $(62.6 \%, 102 / 163)$ than in men $(56.4 \%, 180 / 319)$ (Table 3$)$.

Most fatal AMI cases (65.6\%) occurred out of hospital. This trend was more marked in men $(73.9 \%, 133 / 180)$ than women $(51.0 \%$, 52/102) (Table 4).

Table 1: Diagnostic classification of acute myocardial infarction cases by sex, Santa Clara, Cuba, 2007-2008

\begin{tabular}{|l|r|r|r|}
\hline Classification & Men $n=319$ & Women $n=163$ & Total $n=482$ \\
\hline Non-fatal definite AMI & $139(43.6 \%)$ & $61(37.4 \%)$ & $200(41.5 \%)$ \\
\hline Fatal, definite AMI & $51(16.0 \%)$ & $37(22.7 \%)$ & $88(18.3 \%)$ \\
\hline Fatal, possible AMI & $92(28.8 \%)$ & $35(21.5 \%)$ & $127(26.3 \%)$ \\
\hline Unclassifiable deaths & $37(11.6 \%)$ & $30(18.4 \%)$ & $67(13.9 \%)$ \\
\hline Total & $319(66.2 \%)$ & $163(33.8 \%)$ & $482(100.0 \%)$ \\
\hline
\end{tabular}

Table 2: Cumulative incidence and annual mortality from acute myocardial infarction* by age and sex, Santa Clara, Cuba, 2007-2008

\begin{tabular}{|c|c|c|c|c|}
\hline \multirow[b]{2}{*}{$\begin{array}{l}\text { Age } \\
\text { Group }\end{array}$} & \multicolumn{2}{|c|}{ Cumulative incidence $^{\mathrm{a}}(95 \% \mathrm{CI})$} & \multicolumn{2}{|c|}{ Mortality Rate ${ }^{b}(95 \%$ CI) } \\
\hline & Men & Women & Men & Women \\
\hline $45-64$ & $302(236-368)$ & $99(64-135)$ & $160(113-208)$ & $54(28-80)$ \\
\hline $65-74$ & $932(725-1140)$ & $558(405-710)$ & $553(393-713)$ & $374(249-498)$ \\
\hline $45-74$ & $433(365-501)$ & $195(152-237)$ & $242(192-292)$ & $120(87-153)$ \\
\hline
\end{tabular}

* Definite cases (fatal or not), fatal possible cases and unclassifiable deaths.

a Rates per 100,000 population per year in the period 2007-2008.

${ }^{b}$ Annual mean rates per 100,000 standardized to 2007 world population.
Table 3: Case fatality from acute myocardial infarction, ${ }^{*}$ Santa Clara, Cuba, 2007-2008

\begin{tabular}{|l|r|r|r|}
\hline \multicolumn{3}{|c|}{ Case Fatality } \\
\hline Age Group & \multicolumn{1}{|c|}{$\begin{array}{c}\text { Men } \\
\text { n/N }(\%)\end{array}$} & \multicolumn{1}{c|}{$\begin{array}{c}\text { Women } \\
\text { n/N }(\%)\end{array}$} & \multicolumn{1}{c|}{$\begin{array}{c}\text { Total } \\
\text { n/N(\%) }\end{array}$} \\
\hline 45-54 years & $23 / 52(44.2)$ & $7 / 17(41.2)$ & $30 / 69(43.5)$ \\
\hline 55-64 years & $65 / 112(58.0)$ & $26 / 43(60.5)$ & $91 / 155(58.7)$ \\
\hline 65-74 years & $92 / 155(59.4)$ & $69 / 103(67.0)$ & $161 / 258(62.4)$ \\
\hline 45-64 years & $88 / 164(53.7)$ & $33 / 60(55.0)$ & $121 / 224(54.0)$ \\
\hline 45-74 years & $180 / 319(56.4)$ & $102 / 163(62.6)$ & $282 / 482(58.5)$
\end{tabular}

* Definite cases (fatal or not), and fatal possible cases or unclassifiable deaths. $\mathrm{n}$ : deaths $\mathrm{N}$ : cases of $\mathrm{AMI}$

Table 4: Place of death from acute myocardial infarction by age, sex and case classification; Santa Clara, Cuba, 2007-2008 (n=282)

\begin{tabular}{|l|r|c|c|}
\hline & \multicolumn{3}{|c|}{ Place of death } \\
\hline Variable & $\begin{array}{c}\text { Hospital } \\
n=97(34.4 \%)\end{array}$ & $\begin{array}{c}\text { Other medical } \\
\text { center } \\
n=78(27.7 \%)\end{array}$ & $\begin{array}{c}\text { No medical } \\
\text { center } \\
n=107(37.9 \%)\end{array}$ \\
\cline { 2 - 4 } & $n(\%)$ & $n(\%)$ & $n(\%)$ \\
\hline Sex & $47(26.1)$ & $57(31.7)$ & $76(42.2)$ \\
\hline Male (n=180) & $50(49.0)$ & $21(20.6)$ & $31(30.4)$ \\
\hline Female (n=102) & $6(20.0)$ & $10(33.3)$ & $14(46.7)$ \\
\hline Age group & $30(33.0)$ & $29(31.9)$ & $32(35.1)$ \\
\hline $\begin{array}{l}\text { 45-54 (n=30) } \\
\text { 55-64 (n=91) }\end{array}$ & $61(37.9)$ & $39(24.2)$ & $61(37.9)$ \\
\hline $\begin{array}{l}\text { 65-74 (n=161) } \\
\text { Classification }\end{array}$ & $62(70.5)$ & $9(10.2)$ & $17(19.3)$ \\
\hline $\begin{array}{l}\text { Fatal, definite AMI } \\
(n=88)\end{array}$ & $26(20.5)$ & $46(36.2)$ & $55(43.3)$ \\
\hline $\begin{array}{l}\text { Fatal, possible AMI } \\
(n=127)\end{array}$ & $9(13.4)$ & $23(34.3)$ & $35(52.3)$ \\
\hline $\begin{array}{l}\text { Unclassifiable death } \\
(n=67)\end{array}$ & & & \\
\hline
\end{tabular}

\section{DISCUSSION}

Distribution across diagnostic categories The low proportion of non-fatal definite cases vs. the $58.4 \%$ of REGICOR (-16.9 percentage points)[22] and the $54.1 \%$ of MONICA-Catalonia (-12.6 percentage points) was striking.[33] This could reflect a truly high AMI case fatality in the Santa Clara population, or could be caused by possible underreporting of non-fatal STEMI cases, influenced by unstable out-of-hospital supplies of high-priced marker enzyme immunoassay kits to test for myocardial necrosis.[34] Undercounting of the denominator would thus exaggerate case fatality. It should be noted that some developed countries have also had enzyme immunoassay supply problems.[35]

The percentage of STEMI detection in hospitals in our study was $17.9 \%$, according to unpublished data from the Santa Clara Heart Registry (RECORSA, its Spanish acronym), a value higher than the $16 \%$ mean detected in the 1997 Spanish study Investigation, Specific Search for, and Registry of Acute Coronary Ischemia (IBERICA, its Spanish acronym).[36] In contrast, another Spanish study, the Project for Hospital Myocardial Infarction Registry (PRIAMHO, its Spanish acronym) reported higher percentages of STEMI in both $1995(28.1 \%)$ and 2000 (30.6\%).[37] In the United States, STEMI incidence (using creatine kinase $\mathrm{MB}$ isoenzyme as a necrosis marker) in persons aged $>30$ years increased from $53 \%$ in 1999 to $77.1 \%$ in 2008 , which could be related to improvements in primary prevention, 
as well as a decrease in STEMI case fatalities.[38] It should be noted that with the use of troponins as markers of myocardial necrosis, a $37 \%$ increase in AMI incidence has been found.[39]

Cumulative incidence rates Comparing our incidence, mortality, and case fatality rates is difficult, because there are few populationbased AMI registries, and the methods, age ranges, and periods studied differ. For example, available MONICA results are for the group aged 35-64 years in the period 1981-1995,[21] while REGICOR reports on the group aged 35-74 years in 1990-1999. [22]

Our study excluded one of the MONICA age groups (35-44) for reasons we will discuss; however, we added an age group not analyzed by MONICA (65-74 years) to reach closer to the upper age limit for the Cuban population's life expectancy at birth, which is currently 78 years.[4] There is no doubt that including this age group makes AMI morbidity and mortality surveillance in Santa Clara more useful.

The group aged 35-44 years was excluded because of constraints in the use of marker enzyme immunoassay tests for detecting myocardial necrosis, especially in out-of-hospital urgent care settings (unpublished data from RECORSA). This constraint could theoretically have a greater impact on AMI diagnostic accuracy in the group aged 35-44 years than in older age groups (45-54, 55-64, and 65-74), since acute coronary syndrome in younger people may often be of nonatherothrombotic origin. For example, cardioresonance may be required in this age group to differentiate AMI from myocarditis, which is the most common diagnosis in younger troponinpositive patients presenting with chest pain and unobstructed coronary arteries.[40]

That said, cumulative AMI incidence rate per 100,000 in men (433) was similar to that of MONICA (434),[21] although higher than those of REGICOR (258) [22] and MONICA-Catalonia (315).[33] In women, cumulative incidence per 100,000 (195) was higher than those of MONICA (103),[21] REGICOR (55),[22] and MONICA-Catalonia (80).[33]

In the group aged 65-74 years, our cumulative incidence rates in men and women (932 and 558 per 100,000, respectively) were higher than those of REGICOR (709 and 211, respectively)[22] and one population in the United States (760 and 490, respectively).[41]

To facilitate comparison with MONICA countries, we calculated cumulative incidence rates per 100,000 population in the group aged 45-64 years (302). In men, MONICA rates in the range of 288-318 per 100,000 (corresponding to Cuba: MONICA country ratios of 0.95 to 1.05 , respectively) were considered similar to ours. Only France-Lille[21] was in this range. Only four countries had rates that were lower than Cuba's; they are China, with the lowest (81), Spain, Switzerland, and Italy. The other 16 countries studied had higher rates than Cuba's, with considerable variation among them, from Germany-East, with 370, to Finland-Kuopio, with 718.[21]

In women, incidence rates in the 94-104 per 100,000 range were considered comparable to ours (99). Iceland, Yugoslavia, and Czechoslovakia were in this range, as was the mean for MONICA
(103),[21] while our rate was higher than that of 8 countries, which had figures ranging from 35 (China) to 92 (Australia-Perth),[21] and lower than those of the nine nations in the range of 115 (New Zealand) to 265 (United Kingdom-Glasgow).[21]

Annual mortality rates With the same constraints on international comparisons described earlier, we can say that that the mortality rate per 100,000 in men (242) was higher than those of MONICA (211),[21] REGICOR (59),[22] and MONICA-Catalonia (135). [33] Mortality per 100,000 in women (120) was also higher than those of MONICA (54),[21] REGICOR (12),[22] and MONICACatalonia (43).[33]

To facilitate comparison with MONICA countries, we calculated mortality rates per 100,000 in the $45-64$ age group. No country had rates similar to that found in the Cuban study (160), considering the range of similitude to be 152-168. Five countries had rates lower than Santa Clara, Cuba: China with the lowest (48), Spain, Switzerland, Italy, and Australia,[21] while our rate was lower that those of the other 16 countries studied, with considerable variation among them: from France-Lille (172) to PolandTarnobrzeg (378).[21]

Mortality rates per 100,000 in women ranging from 51 to 57 were considered similar to ours (54); Yugoslavia and Czechoslovakia, as well as the MONICA mean (54), were in this range. The Cuban rate was higher than those of 11 countries: Spain with the lowest (16), Italy-Friuli, China, Iceland, Australia-Perth, Sweden-Northern, France-Lille, Lithuania, Canada, Finland-Kuopio, and Germany-East, but lower that those of 7 nations: New Zealand, Russia-Moscow/Intervention, Belgium-Charleroi, United States, Denmark, PolandWarsaw and the United Kingdom-Glasgow, the latter with the highest (123).[21]

Significant gradients in cardiovascular morbidity and mortality rates can exist within a country. In Spain, for example, IHD mortality in men in Las Palmas Province (164.4 per 100,000) in 1998 was 2.4 times that of Segovia (67.7). These regional differences in Spain can be explained by variations in prevalence of factors affecting cardiovascular risk including: consumption of fish, wine, and saturated fats; socioeconomic status; and quality and accessibility of health care.[42]

Population case fatality AMI case fatality in men for the period 2007-2008 (56.4\%) was higher than mean case fatalities in MONICA (49\%),[21] REGICOR (41.6\%),[22] and MONICACatalonia (46\%).[33] In women, AMI case fatality was also higher $(62.6 \%)$ than those of MONICA (53.8\%),[21] REGICOR $(45.3 \%),[22]$ and MONICA-Catalonia (53\%),[33] but our female:male case fatality ratio was similar to those of the three studies (approximately 1.1 in all cases). More advanced age, prevalence of comorbidity-especially diabetes, hypertension and heart failure-delays in reaching hospital, and treatment intensity have been suggested as factors related to higher population and hospital AMI case fatalities in women.[43,44] According to a recent study comparing IHD mortality in Cuba and Spain by sex, Cuban women may have greater cardiovascular vulnerability,[29] a finding that calls for future studies.

To facilitate comparison with MONICA, case fatality rates in our population were calculated in the 45-64 age group. 
The MONICA case fatality rates of $51 \%$ to $56 \%$ in men are considered similar to ours $(53.7 \%)$. Yugoslavia, Denmark, Czechoslovakia, and Lithuania were in that range. Our rate was higher than those of 13 countries: Sweden, with the lowest rate $(36.1 \%)$, Australia-Perth, Spain, Switzerland, Iceland, Canada, Italy-Friuli, United Kingdom-Belfast, Finland-Kuopio, United States, New Zealand, Germany-East, and BelgiumCharleroi. It was lower than 4 nations: China, France-Lille, Russia-Moscow/Intervention, and Poland-Tarnobrzeg, the last with the highest rate $(82.7 \%)$.[21]

MONICA population-level case fatality rates in women ranging from $52 \%$ to $58 \%$ were considered similar to ours $(55 \%)$. The overall MONICA mean was in this range, as were those of the United States, Lithuania, Czechoslovakia and Denmark. Our rate in women was higher than those of 10 countries: Canada, with the lowest rate $(33.6 \%)$, Iceland, Sweden-Northern, Finland-Kuopio, Australia-Perth, Spain, United Kingdom-Glasgow, Italy-Friuli, Yugoslavia, and New Zealand. It was lower than those of 6 countries: PolandWarsaw, Belgium-Charleroi, Germany-East, Russia-Moscow/ Intervention, France-Lille, and China, the last with the highest rate $(73.6 \%) \cdot[21]$

Place of death by age, sex and case classification The proportion of out-of-hospital deaths $(65.6 \%)$ was similar to that of REGICOR $(66.8 \%)$, although there was a smaller difference between men and women in the Spanish study $(67.8 \%$ and $63.2 \%$ in men and women, respectively, vs $73.1 \%$ and $51 \%$ in our study).[22]

In Cuba, the percentage of out-of-hospital fatal AMI cases reported nationally in 2007 (58.5\%) was lower than seen in our municipal study; differences in classification of out-of-hospital deaths may have contributed to this result.[45]

In general, population-based AMI registries show that some two thirds of deaths occur out of hospital, which underscores the critical role of primary care in reducing mortality from AMI.[22] This proportion is higher in men than women, since the latter die primarily of heart failure rather than acute complications such as ventricular arrhythmias.[43]

The majority of fatal definite cases occur in hospitals, where diagnostic tools are more readily available, as well as more highly trained physicians in handling cardiovascular emergencies. Most fatal cases of unclassifiable deaths, in contrast, occur out of hospital. This highlights the need to obtain further information from physicians and families of deceased patients.[46]

Study constraints These results should be viewed with caution, since:

- The MONICA algorithm was not fully employed, because outof-hospital unclassifiable deaths were not investigated. Conducting an inquiry to obtain information would permit more accurate characterization of these cases and is the most onerous part of maintaining a population-based AMI registry.[46]

- Unstable out-of-hospital supply of cardiac marker enzyme immunoassay test kits in Cuba could lead to underreporting of STEMI and hence, underestimation of incidence rates and overestimation of AMI case fatality rates.
- Rates cannot be extrapolated from Santa Clara to other areas of Cuba.

- The study did not analyze the same age ranges as MONICA (35-64 years)[21] or REGICOR (35-74 years),[22] making comparison with these studies difficult, except for groups aged 45-54, 55-64, and 65-74 years (which did coincide with REGICOR).

As one of REGICOR's principle investigators said, "Is it better to have a small-scale registry... than to have none at all if the "ideal" registry cannot be obtained? The answer must be another question: Is anything better available? If not, there is no choice but to use available information, expressing appropriate reservations about its generalization..."[19]

Study importance For the first time in Cuba, AMI incidence, mortality, and population case fatality rates have been estimated using the WHO MONICA algorithm, if only partially. The study also offers a simple approach to comparing rates among countries.

Finally, the results and experiences of this study have made it possible to obtain financing from the Ministry of Science, Technology, and Environment (CITMA, its Spanish acronym) for RECORSA, a multidisciplinary registry involving epidemiologists, cardiologists, intensive care specialists, general practitioners, pathologists, statisticians, and nurses; it is backed by the provincial health department and the government of Villa Clara province.

Information on incidence, mortality, case fatality and trends resulting from the creation and maintenance of a populationbased AMI registry in Santa Clara will be useful in assessing effectiveness of specific prevention strategies, identifying and prioritizing high-risk populations for prevention and management programs, and generating reference values to detect environmental, occupational or other health risks in population groups.[5]

A recent article noted that creating a national $A M I$ registry is a priority for the Cuban Ministry of Public Health (MINSAP),[15] and RECORSA's investigators have the experience to collaborate in this endeavor.

\section{CONCLUSIONS}

Case fatality from acute myocardial infarction in the Santa Clara population was high, especially in women. Two thirds of acute myocardial infarction victims died out of hospital, an even higher proportion in men. It is recommended that the AMI registry be completed by investigating out-of-hospital unclassifiable deaths, expanding it to include the 35-44 age group, and that the supply of cardiac marker enzyme immunoassay test kits in Santa Clara be stabilized.

\section{ACKNOWLEDGMENTS}

The authors are grateful to professors Jaume Marrugat, Roberto Elosua, John Vila and María Grau, of the Cardiovascular Epidemiology and Genetics Group of the Instituto de Investigación del Hospital del Mar de Barcelona for their assistance in conducting this study. - M 


\section{REFERENCES}

1. Yusuf S, Reddy S, Ounpuu S, Anand S. Global burden of cardiovascular diseases. Part I: General considerations, the epidemiologic transition, risk factors, and impact of urbanization. Circulation. 2001 Nov 27;104(22):2746-53.

2. WHO. Estadísticas Sanitarias Mundiales [Internet]. Geneva: World Health Organization; 2009 [cited 2011 Feb 10]. 149 p. Available from http://www.who.int/whosis/whostat/2009/es/ index.html. Spanish.

3. Seuc AH, Domínguez Alonso E, Torres Vidal RM, Varona Pérez P. Algunas precisiones acerca de la mortalidad por enfermedades cardiovasculares en Cuba [Internet]. Rev Cub Salud Pública. 2011 Jan-Mar [cited 2011 Feb 10]; 37(1):19-33. Available from: http://www.bvs.sld.cu/revistas/ spu/vol37_01_11/spu04111.htm. Spanish.

4. Ministry of Public Health (CU). Anuario Estadístico de Salud 2009. Havana: Ministry of Public Health (CU); 2010 [cited 2011 Feb 10]. Available from: http://files.sld.cu/dne/files/2010/04/ anuario-2009e3.pdf

5. Medrano Albero MJ, Boix Martínez R, Cerrato Crespán E, Ramírez Santa-Pau M. Incidencia y prevalencia de cardiopatía isquémica y enfermedad cerebrovascular en España: Revisión sistemática de la literatura. Rev Esp Salud Pública. 2006;80:5-15. Spanish.

6. Smith SC Jr, Jackson R, Pearson TA, Fuster $\mathrm{V}$, Yusuf S, Faergeman $\mathrm{O}$, et al. Principles for National and Regional Guidelines on CVD Prevention: a Scientific Statement From the World Heart and Stroke Forum. Circulation. 2004 Jun 29;109(25):3112-21.

7. Ríos Massabot NE, Fernández Viera RM, Jorge Pérez ER. Los registros médicos en Cuba. Rev Cub Salud Pública. 2005;31(4):345-52. Spanish.

8. Batista Moliner R, Landrove Rodríguez $O$, Bonet Gorbea M, Feal Cañizares P, Ramírez M. Sistema de vigilancia de enfermedades no transmisibles en Cuba. Rev Cub Hig Epidemiol. 2000 May-Aug;38(2):77-92. Spanish.

9. Cañizares Pérez M, Barroso Utra I, Alfonso León A, García Roche R, Alfonso Sagué K, Chang de la Rosa M, et al. Estimaciones usadas en diseños muestrales complejos: aplicaciones en la encuesta de salud cubana del año 2001. Rev Panam Salud Pública. 2004 Mar 31;15(3):176-84. Spanish.

10. Debs G, La Noval $R$, Dueñas Herrera $A$ González Pagés JC. Prevalencia de factores de riesgo coronario en "10 de Octubre". Rev Cub Cardiol Cir Cardiovasc. 2001;15(1):14-20. Spanish.

11. Espinosa $A D$, Ordúñez $P O$, Alvarez FC, Vázquez LE, Armas Y, Diez E, et al. La Web de Cienfuegos. El Proyecto Global de Cienfuegos. Diez Años después [Internet]. Cienfuegos (CU): E Navegante; 2010 [cited 2010 Sep 10] [about 3 screens]. Available from: http://www.fac.org.ar/ cvirtual/tlibres/tnn2350/tnn2350c.html. Spanish.

12. Morejón Giraldoni AF. [Concerning the regiona initiatives to promote cardiovascular health in Cienfuegos city]. MediSur. 2008;6(3):108-11. Spanish.

13. Benet Rodríguez $M$, Morejón Giraldoni $A$ Espinosa Brito AD, Landrove Rodríguez O, Peraza Alejo D, Ordúñez García PO. Factores de Riesgo para Enfermedades Crónicas en Cienfuegos, Cuba 2010. Resultados preliminares de CARMEN II. MediSur. 2010;8(2):56-9. Spanish.

14. Ordúñez P, Cooper R, Espinosa A, Iraola M, Bernal JL, La Rosa Y. Enfermedades cardiovasculares en Cuba: determinantes para una epidemia y desafíos para la prevención y control. Rev Cub Salud Pública. 2005;31(4):270-84. Spanish.
15. Giraldo G. Three-Pronged Innovation to Improve Care for Acute Myocardial Infarction Patients in Cuba. MEDICC Rev. 2010 Jul;12(3):11-6.

16. Icaza G, Núñez L, Marrugat J, Mujica V, Escobar $M C$, Jiménez AL, et al. Estimación de riesgo de enfermedad coronaria mediante la función de Framingham adaptada para la población chilena Rev Med Chil. 2009 Oct;137(10):1273-82. Spanish.

17. Caccavo A, Álvarez A, Bello FH, Ferrari AE, Carrique $\mathrm{AM}$, Lasdica $\mathrm{EA}$, et al. Incidencia poblacional del infarto con elevación del ST o bloqueo de rama izquierda a lo largo de 11 años en una comunidad de la provincia de Buenos Aires. Rev Argent Cardiol. 2007 May-Jun;75(3):185-8. Spanish.

18. Ferrante D, Tajer CD. ¿Cuántos infartos hay en la Argentina? Rev Argent Cardiol. 2007 MayJun;75(3):161-2. Spanish.

19. Marrugat J, Sala J. Registros de morbimortalidad en cardiología. Rev Esp Cardiol. 1997;50:48-57. Spanish.

20. Cabadés A. El registro REGICOR y la epidemiología del infarto de miocardio en España: se hace camino al andar. Rev Esp Cardiol. 2007 Apr;60(4):342-5. Spanish.

21. Tunstall-Pedoe $\mathrm{H}$, Kuulasmaa $\mathrm{K}$, Mähönen $\mathrm{M}$, Tolonen H, Ruokokoski E, Amouyel P. Contribution of trends in survival and coronary-event rates to changes in coronary heart disease mortality: 10-year results from 37 WHO MONICA project populations. Monitoring trends and determinants in cardiovascular disease. Lancet. 1999 May 8;353(9164):1547-57.

22. Gil M, Martí H, Elosúa R, Grau M, Sala J, Masiá $\mathrm{R}$, et al. Análisis de la tendencia en la letalidad, incidencia y mortalidad por infarto de miocardio en Girona entre 1990 y 1999. Rev Esp Cardiol. 2007 Apr;60(4):349-56. Spanish.

23. Marrugat J, Subirana I, Comín E, Cabezas C, Vila J, Elosua R, et al. Validity of an adaptation of the Framingham cardiovascular risk function: the VERIFICA study. J Epidemiol Community Health. 2007 Jan;61(1):40-7.

24. Grau M, Guxens M, Subirana I, Fitó M, Covas MI, Jacquemin B, et al. South-to-North gradient in lipid peroxidation in men with stable coronary artery disease in Europe. Eur Heart J. 2007 Dec;28(3):2841-9.

25. Myocardial Infarction Genetics Consortium Kathiresan S, Voight BF, Purcell S, Musunuru K, Ardissino D, et al. Genome-wide association of early-onset myocardial infarction with single nucleotide polymorphisms and copy number variants. Nat Genet. 2009 Mar;41(3):334-41.

26. Grau M, Subirana I, Elosua R, Solanas P, Ramos $\mathrm{R}$, Masia R, et al. Trends in cardiovascular risk factor prevalence (1995-2000-2005) in northeastern Spain. Eur J Cardiovasc Prev Rehabil. 2007 Oct;14(5):653-9.

27. Morales A, Marrugat J, Coca A. Limitaciones de la valoración clínica de obesidad: Reflexiones a propósito de la Declaración de la American Heart Association de 2006. Rev Esp Cardiol. 2007 Sep;60(9):992-3. Spanish

28. Marrugat J, Morales A, Luna $\mathrm{Y}$, Madrazo $\mathrm{Y}$, Carmona $\mathrm{R}$, Masia $\mathrm{R}$, et al. Comparison of the cardiovascular risk of workers in Spain and Cuba [Internet]. World Congress of Cardiology 2006. September2-6. Barcelona, Spain. 2006 [cited 2010 Sep 10]; [about 2 screens]. Available from: http://spo.escardio.org/AbstractDetails. aspx?id=47386\&eevtid $=15$

29. Morales A, Dueñas R, Martínez B, Rodríguez A, Pérez GP, Grau M, et al. Cuba singularity: different environmental and coronary heart disease mortality but similar life expectancy at birth than Spain [Internet]. European Congress of Cardi- ology 2009. August 29-September 2. Barcelona, Spain. 2009 [cited 2010 Sep 10]; [about 2 screens]. Available from: http://spo.escardio.org/ eslides/view .aspx? ?eevtid $=33 \& f p=3133$

30. Grau M, Morales Salinas A, Redondo A, Elosua R, Ramos R, Marrugat J, et al. Distribución de los factores de riesgo cardiovascular por categorías de actividad física en hombres y mujeres con y sin obesidad abdominal [Internet]. Rev Esp Cardiol. 2009 [cited 2010 Sep 10];62 Supl 3:1226. Available from: http://www.congresosec. org/2009/agenda/docs/22823.pdf. Spanish.

31. Manual of The MONICA Project [Internet] Geneva: World Health Organization; 2000 [cited 2010 Sep10]. Available from: http://www.ktl.fi/ publications/monica/manual/index.htm

32. Waterhouse J, Muir CS, Correa P, Powell J, eds. Cancer incidence in five continents. Lyon: IARC 1976. $456 \mathrm{p}$

33. Sans S, Puigdefábregas A, Paluzie G, Monterde $D$, Balaguer-Vintró I. Increasing trends of acute myocardial infarction in Spain: the MONICA-Catalonia study. Eur Heart J. 2005 Mar;(5)26:505-15.

34. de Vos P, Van der Stuyft P. The right to health in times of economic crisis: Cuba's way. Lancet. 2009 Nov 7:374(9701):1575-6.

35. Bardají A, Bueno H, Fernández-Ortiz A, Heras M. Aplicabilidad de la nueva definición de infarto de miocardio y opinión de los cardiólogos españoles. Rev Esp Cardiol. 2003 Jan;56(1):23-8. Spanish.

36. Fiol M, Cabadés A, Sala J, Marrugat J, Elosua R, Vega G, et al. Variabilidad en el manejo hospitalario del infarto agudo de miocardio en España. Estudio IBERICA (Investigación, Búsqueda Específica y Registro de Isquemia Coronaria Aguda). Rev Esp Cardiol. 2001 Apr;54(4):443-52. Spanish.

37. Herasa M, Marrugat J, Arósc F, Boscha X, Enerod J, Suárez MA, et al. Reducción de la mortalidad por infarto agudo de miocardio en un período de cinco años. Rev Esp Cardiol. 2006 Mar;59(3): 200-8. Spanish.

38. Yeh RW, Sidney S, Chandra M, Sorel M, Selby JV, Go AS. Population Trends in the Incidence and Outcomes of Acute Myocardial Infarction. N Engl J Med. 2010 Jun 10;362(23):2155-65.

39. French JK, White HD. Clinical implications of the new definition of myocardial infarction. Heart. 2004 Jan;90(1):99-106.

40. Assomull RG, Lyne JC, Keenan N, Gulati A, Bunce $\mathrm{NH}$, Davies SW, et al. The role of cardiovascular magnetic resonance in patients presenting with chest pain, raised troponin, and unobstructed coronary arteries. Eur Heart J. 2007 May;28(10):1242-9.

41. Rosamond W, Flegal K, Furie K, Go A, Greenlund K, Haase N, et al. Heart Disease and Stroke Statistics-2008 Update: A Report From the American Heart Association Statistics Committee and Stroke Statistics Subcommittee. Circulation. 2008 Jan 29;117(4):25-146.

42. Boix R, Aragonés N, Medrano MJ. Tendencias en la mortalidad por cardiopatía isquémica en 50 provincias españolas. Rev Esp Cardiol. 2003:56(9):850-6. Spanish.

43. Marrugat J, Sala J, Aboal J. Epidemiología de las enfermedades cardiovasculares en la mujer. Rev Esp Cardiol. 2006 Jan;59(1):264-74. Spanish.

44. Figueras J. Mayor mortalidad en la angioplastia primaria en la mujer. ¿Sigue el enigma del sexo? Rev Esp Cardiol. 2006;59(11):1097-9. Spanish.

45. Ministry of Public Health (CU). Indicadores Estadísticos Principales. Cuba 2009 [Internet]. 2009 [cited 2010 Sep 10]. Available from: http:/ www.sld.cu/galerias/ppt/sitios/cardiologia/ indicadores_estadisticos_principales.ppt. Spanish. 
46. García J, Cirera L, Tormo MJ, Martínez C Contreras J, García J, et al. Utilidad del boletín estadístico de defunción para la identificación de muertes extrahospitalarias en un registro poblacional de infartos agudos de miocardio. Rev Esp Cardiol. 2001 Sep;54(9):1041-7. Spanish.

\section{THE AUTHORS}

Alberto Morales Salinas (Corresponding author: albert@cardiovc.sld.cu), physician with specialties in cardiology and family medicine and a master's degree in public health, Ernesto Che Guevara Heart Center, Santa Clara, Villa Clara, Cuba.

Yuri Madrazo Gutiérrez, physician with specialties in biostatistics and family medicine, Villa Clara Provincial Health Department, Santa Clara, Cuba.
José I. Ramírez Gómez, physician with specialties in cardiology and family medicine, Arnaldo Milián Castro University Hospital, Santa Clara, Cuba.

Luis Castañeda Casarvilla, physician with specialties in internal medicine and intensive care and a doctorate in medical sciences, Celestino Hernández Robau University Hospital, Santa Clara, Cuba.

Wilfredo Machín Cabrera, physician specializing in cardiology with a doctorate in medical sciences, Comandante Manuel Piti Fajardo Hospital, Santa Clara, Cuba.

Licet Álvarez Guerra, physician with specialties in epidemiology and family medicine, Villa Clara Provincial Health Department, Santa Clara, Cuba.
Regla Angulo Pardo, physician specializing in family medicine with a master's degree in public health, Villa Clara Provincial Health Department, Santa Clara, Cuba.

Raúl Dueñas Fernández, physician specializing in cardiovascular surgery with a master's degree in public health, Ernesto Che Guevara Heart Center, Santa Clara, Cuba.

Roberto Bermúdez Yera, physician specializing in cardiology, Ernesto Che Guevara Heart Center, Santa Clara, Cuba and Santa Clara Heart Registry, Santa Clara, Cuba.

Submitted: September 20, 2010

Approved for publication: September 21, 2011 Disclosures: None 